\title{
Analiza zaburzeń zgryzu u uczniów powiatu kolskiego
}

\author{
Analysis of occlusion disorders in children from the district of Koło \\ ${ }^{1}$ Katedra i Klinika Ortopedii Szczękowej i Ortodoncji, Uniwersytet Medyczny im. Karola Marcinkowskiego w Poznaniu \\ 2 Prywatna Praktyka Medyczna w Kole \\ ${ }^{3}$ Zakład Organizacji i Zarządzania w Opiece Zdrowotnej, Uniwersytet Medyczny im. Karola Marcinkowskiego w Poznaniu
}

DOI: http://dx.doi.org/10.20883/df.2017.3

\begin{abstract}
Streszczenie
Wstęp. W Polsce częstość występowania wad zgryzowo-zębowych wśród dzieci i młodzieży jest wysoka oraz zróżnicowana i kształtuje się w przedziale od $36,7 \%$ do $79 \%$. Do najczęściej występujących chorób narządu żucia zalicza się wady zgryzu, co wskazuje na rangę zagadnienia, zważywszy na fakt, iż wśród nastolatków problem ten jest coraz bardziej przez nich zauważalny i wywołuje potrzebę korzystania z wizyt w gabinecie ortodontycznym celem poprawy samooceny oraz wzrostu poczucia własnej wartości.

Cel. Celem pracy była analiza występowania zaburzeń zwarciowych wg klas Angle’a oraz nieprawidłowości zębowych u dzieci 12- i 13-letnich wschodniej Wielkopolski.

Materiał i metody. Badaniu poddano grupę 76 dzieci obojga płci w wieku 12 i 13 lat, uczęszczających do jednej ze szkół powiatu kolskiego w Wielkopolsce. Dzieci w wieku 12 lat (37 osób) i 13 lat (39 osób) zbadano pod kątem występowania wad zgryzu i nieprawidłowości zębowych, takich jak: ektopia, transpozycja, retruzja, protruzja, mesoinklinacja, distoinklinacja, palatopozycja, westibulopozycja, rotacja, reinkluzja, ząb zatrzymany, ząb przetrwały oraz występowania lub braku stłoczeń w odcinku przednim, oddzielnie dla górnego i dolnego łuku zębowego, a także zależności wad w oparciu o klasę Angle'a.

Wyniki. Prawidłowy zgryz mieszczący się w granicach normy stwierdzono zaledwie u 18,9\% badanych, tzn. u $81,1 \%$ odnotowano nieprawidłowości. Wśród 12-latków najwyższy odsetek stanowiły wady dotylne, bo aż 70,3\%, z czego spośród 16 dziewcząt dotyczyły one 88,9\%, natomiast wśród 10 chłopców wystąpiły one w 52,6\%. Następną grupę pod kątem wielkości występowania stanowiły wady pionowe 29,7\% - odpowiednio u 5 dziewcząt (27,8\%), u 6 chłopców 31,6\% i wady poprzeczne 13,5\% - odpowiednio u 3 dziewcząt $(16,7 \%)$ oraz u 2 chłopców 10,5\%.

Wnioski. Częstość występowania wad zgryzu u dzieci w wieku szkolnym w grupie 12- i 13-latków we wschodniej Wielkopolsce była wysoka, z przewagą wad zgryzu u dzieci 12-letnich.
\end{abstract}

Słowa kluczowe: wady zgryzu, nieprawidłowości zębowe, klasa Angle’a, dzieci.

\begin{abstract}
Introduction. In Poland, the incidence of malocclusions among children and adolescents is high and varies from $36.7 \%$ to $79 \%$. This means malocclusions are one of the most common diseases which indicates the gravity of the problem, given that among teenages it is becoming a more and more noticeable disturbance resulting in a need for orthodontic visits in order to achieve a better self acceptance and also improve the self-esteem.

Aim. The aim was to analyse the prevalence of occlusal disorders according to Angle's classification as well as dental anomalies in children of 12 and 13 years old in the region of eastern Wielkopolska.

Material end methods. The study involved 76 children of both sexes aged 12 and 13 attending one of the schools in the Koło district. These 12 and 13 years olds were placed into two groups of 37 and 39 children respectively and were examined in respect of the occurrence of malocclusion; as well as teeth abnormalities such as ectopic position, transposition, retrusion, protrusion, mesioinclination, distoinclination, palatoposition, westibuloposition, rotation, reinclusion, teeth impaction, delayed eruption, and the presence or absence of crowding in the anterior region separately for upper and lower dental arches, along with disorders based on Angle's classification.

Results. Correct occlusion within normal limits was only found in $18.9 \%$ of cases, while in the other $81.1 \%$ irregularities were reported. In the group of 3712 -years-old children distocclusion had the highest prevalence of $70.3 \%$, of which $88.9 \%$ relate to 16 girls, while $52.6 \%$ relate to 10 boys. In respect of frequency, the second group of malocclusions were vertical defects $-29.7 \%$, found in 5 girls $(27.8 \%)$ and 6 boys $(31.6 \%)$; and the third group were transversal defects $13.5 \%$, found in 3 girls $(16.7 \%)$ and 2 boys $(10.5 \%)$ respectively.

Conclusions. The prevalence of malocclusions in 12 to 13-year old schoolchildren in the region of eastern Wielkopolska was high among the majority in 12 year-old children.
\end{abstract}

Keywords: malocclusion, dental abnormalities, class Angle, children. 


\section{Wstęp}

W Polsce, jak podają Onoszko i wsp., Rojek i Lisiecka, Grodzka i wsp. oraz Osmólska-Bogucka i wsp., częstość występowania wad zgryzowo-zębowych w populacji dzieci i młodzieży jest wysoka i zróżnicowana; w zależności od autorów waha się od $36,7 \%$ do $79 \%$ [1-4]. Wady zgryzu zostały zaliczone do najczęściej występujących chorób i zaburzeń rozwojowych narządu żucia dzieci w wieku szkolnym. Występowanie wad zgryzu u polskich dzieci wydaje się być aktualnym zagadnieniem, zważywszy na ich liczbę w wieku szkolnym. Najczęściej potrzeba leczenia wady zgryzu u dziecka wynika z odczucia rodzica, natomiast nastolatki częściej same zauważają powstałe nieprawidłowości zgryzowo-zębowe. Nierzadko pojawienie się nastolatka w gabinecie ortodontycznym jest podyktowane potrzebą akceptacji wyglądu oraz akceptacji przez środowisko rówieśników. Zagadnienie to sprowadza wygląd uzębienia i uśmiechu do poziomu psychospołecznego, gdzie kształtuje się samoocena nastolatka, poczucie wartości, a tym samym poczucie jakości życia. Sieja i Kawala zwracają uwagę na analizę makroestetyczną dotyczącą pomiaru tkanek miękkich twarzy, analizę miniestetyczną określającą odpowiednie elementy uśmiechu oraz analizę mikroestetyczną oceniającą uzębienie [5]. Problem występowania wad narządu żucia, jak podaje wielu autorów, dotyczy wszystkich populacji na całym świecie, nie zależy od rasy, pochodzenia etnicznego, a także statutu społeczno-ekonomicznego [6-9]. Celem pracy jest analiza nasilenia występowania zaburzeń zwarciowych (klas Angle’a) oraz nieprawidłowości zębowych u dzieci 12- i 13-letnich w regionie wschodniej Wielkopolski.

\section{Materiał i metody}

Materiał badany stanowiło 76 dzieci w wieku szkolnym (obojga płci) z powiatu kolskiego: grupa 12-latków (37 osób) i grupa 13-latków (39 osób), będących uczniami szkół podstawowych i gimna- zjów. Na przeprowadzenie badań została wydana zgoda Komisji Bioetycznej przy Uniwersytecie Medycznym im. Karola Marcinkowskiego w Poznaniu (Uchwała nr 907/12). Dyrekcje szkół podstawowych i gimnazjalnych wyraziły zgodę na spotkania informacyjne o prowadzonych badaniach w trakcie zebrań rodzicielskich. Rodzic/opiekun prawny każdej badanej osoby wyraził pisemną zgodę na przeprowadzenie badania oraz zapoznał się z pisemną informacją o sposobie przeprowadzania i celach dobrowolnych, bezpłatnych badań. Jako kryterium zakwalifikowania dziecka uwzględniano wiek i uczęszczanie do jednej ze szkół w powiecie kolskim.

W trzech płaszczyznach przestrzennych poddano analizie stosunki zgryzowe, oceniając klasy Angle'a stosowane do charakterystyki zgryzu w wymiarze przednio-tylnym, rozpatrując stronę prawą i lewą. Zostało odnotowane występowanie: I klasy Angle'a - cechującej się guzkiem policzkowym przednim pierwszego górnego stałego zęba trzonowego położonym w przedniej policzkowej bruździe międzyguzkowej pierwszego dolnego stałego zęba trzonowego; niepełnej (guzkowej) II klasy Angle'a - guzek policzkowy przedni pierwszego górnego stałego zęba trzonowego styka się z guzkiem policzkowym przednim pierwszego dolnego stałego zęba trzonowego; II klasy Angle'a (pełnej) - charakteryzującej się guzkiem policzkowym przednim pierwszego górnego stałego położonym w przestrzeni pomiędzy drugim dolnym zębem przedtrzonowym i pierwszym dolnym zębem trzonowym; niepełnej (guzkowej) III klasy Angle'a - guzek policzkowy przedni pierwszego górnego stałego zęba trzonowego pozostaje w kontakcie z guzkiem policzkowym tylnym pierwszego dolnego stałego zęba trzonowego; III klasy Angle'a (pełnej) - odznaczającej się guzkiem policzkowym przednim pierwszego górnego stałego zęba trzonowego umiejscowionego w przestrzeni pomiędzy pierwszym i drugim stałym dolnym zębem trzonowym (Rycina 1).
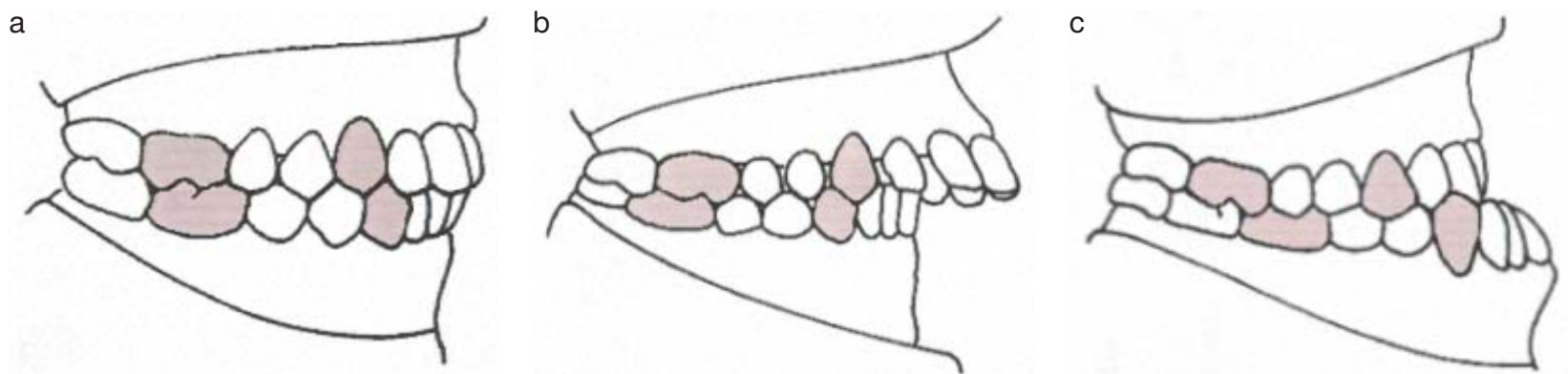

Rycina 1. a) I klasa Angle’a i I klasa kłowa; b) II klasa Angle’a i II kasa kłowa; c) III klasa Angle’a i III klasa kłowa. Źródło: Zarys współczesnej ortodoncji pod redakcją Ireny Karłowskiej, Wydawnictwo Lekarskie PZWL, Warszawa 2016

Figure 1. a) I Angle Class - I class malocclusion; b) II Angle Class - II class malocclusion; c) III Angle Class - III class malocclusion 
Następnie analizowano nagryz poziomy, który stanowi przednio-tylną relację zębów siecznych obu łuków zębowych, mierzony przy maksymalnym zaguzkowaniu, od powierzchni wargowej zęba siecznego dolnego do brzegu siecznego górnego zęba przyśrodkowego. Powiększenie nagryzu poziomego jest uznawane za cechę wady dotylnej (tyłozgryzy), natomiast jego pomniejszenie jest uznawane za objaw wady doprzedniej (przodozgryzy).

Analizowano również nagryz pionowy, definiujący pionowe relacje zębów siecznych obu łuków zębowych, głębokość zachodzenia górnych zębów siecznych na jednoimienne dolne. Nagryz pionowy określa się jako rzut brzegu siecznego górnego przyśrodkowego zęba siecznego na powierzchnię wargową dolnego przyśrodkowego zęba siecznego. Za normę uważa się przykrycie do 1/2 wysokości korony zęba siecznego dolnego.

Kolejnym badaniem była ocena obecności i rodzajów nieprawidłowości zębowych dotyczących głównie położenia - ektopii, transpozycji, retruzji, protruzji, mesoinklinacji, distoinklinacji, palatopozycji, westibulopozycji, rotacji, reinkluzji, zębów zatrzymanych i przetrwałych, a także występowania lub braku stłoczeń w odcinku przednim oddzielnie górnego i dolnego łuku zębowego.

W celu weryfikacji uzyskanych wyników klinicznych uzyskane dane poddano analizie statystycz- nej z użyciem programów Statistica 10 i StatXact 8. Zastosowano testy: chi-kwadrat, chi-kwadrat z poprawką Yatesa, dokładny Fishera lub Fishera-Freemana-Haltona. Jako poziom istotności przyjęto $\alpha=0,05$.

\section{Wyniki}

Normę zgryzową stwierdzono u 18,9\% badanych, a więc u $81,1 \%$ odnotowano nieprawidłowości. Najczęściej występującą nieprawidłowością były wady dotylne (70,3\% badanych 12-latków), następnie wady pionowe $(29,7 \%)$ i wady poprzeczne (13,5\%) (Tabela 1). Analiza statystyczna wykazała u 12-latków istotną zależność pomiędzy występowaniem wady dotylnej a klasą kłową strony prawej $(p=0,000007)$ i lewej $(p=0,00012)$. Największy odsetek badanych 12-latków miał I klasę Angle'a, $48,6 \%$ po stronie prawej i $56,7 \%$ po stronie lewej. Klasę II Angle'a, czyli wady dotylne, stwierdzono u $27 \%$ po stronie prawej i 21,6 \% po stronie lewej. Klasę III Angle'a stwierdzono obustronnie tylko u jednego chłopca. Guzkową relację pierwszych zębów trzonowych wykryto obustronnie u 6 badanych (Tabela 2). Normę zgryzową - I klasę kłową stwierdzono po prawej stronie u $21,6 \%$ i $27 \%$ po lewej. Najmniejszy odsetek III klasy kłowej u 12-latków odnotowano obustronnie u 2,7\%, a II klasa kłowa występowała u $62,2 \%$ po stronie prawej i $56,8 \%$ po stronie lewej. Najczęstszą relacją

Tabela 1. Częstość występowania nieprawidłowości zębowo-zgryzowych u 12-latków

Table 1. The prevalence of dental-occlusal abnormalities in 12-year-olds

\begin{tabular}{|l|c|c|c|c|c|c|}
\hline \multirow{2}{*}{ Rodzaj nieprawidłowości } & \multicolumn{2}{|c|}{$\begin{array}{c}\text { Ogółem } \\
\mathrm{N}=37\end{array}$} & \multicolumn{2}{c|}{$\begin{array}{c}\text { Dziewczęta } \\
\mathrm{N}=18\end{array}$} & \multicolumn{2}{c|}{$\begin{array}{c}\text { Chłopcy } \\
\mathrm{N}=19\end{array}$} \\
\cline { 2 - 7 } & $\mathrm{N}$ & $\%$ & $\mathrm{~N}$ & $\%$ & $\mathrm{~N}$ & $\%$ \\
\hline wada poprzeczna & 5 & 13,5 & 3 & 16,7 & 2 & 10,5 \\
\hline wada pionowa & 11 & 29,7 & 5 & 27,8 & 6 & 31,6 \\
\hline wada dotylna & 26 & 70,3 & 16 & 88,9 & 10 & 52,6 \\
\hline wada doprzednia & 2 & 5,4 & 0 & 0 & 2 & 10,5 \\
\hline
\end{tabular}

Tabela 2. Obustronna ocena klasy Angle'a u 12-latków

Table 2. Bilateral evaluation of the Angle class for 12-year-olds

\begin{tabular}{|l|c|c|c|c|c|c|}
\hline \multirow{2}{*}{} & \multicolumn{2}{|c|}{$\begin{array}{c}\text { Razem } \\
\mathrm{N}=37\end{array}$} & \multicolumn{2}{c|}{$\begin{array}{c}\text { Dziewczęta } \\
\mathrm{N}=18\end{array}$} & \multicolumn{2}{c|}{$\begin{array}{c}\text { Chłopcy } \\
\mathrm{N}=19\end{array}$} \\
\cline { 2 - 7 } & $\mathrm{N}$ & $\%$ & $\mathrm{~N}$ & $\%$ & $\mathrm{~N}$ & $\%$ \\
\hline klasa Angle'a strona prawa & \multicolumn{7}{|c|}{} \\
\hline I & 18 & 48,6 & 8 & 44,4 & 10 & 52,6 \\
\hline II & 10 & 27 & 5 & 27,8 & 5 & 26,3 \\
\hline III & 1 & 2,7 & 0 & 0 & 1 & 5,2 \\
\hline IV (guzkowa) & 6 & 16,2 & 4 & 22,2 & 2 & 10,5 \\
\hline klasa Angle'a strona lewa & \multicolumn{7}{|l|}{} \\
\hline I & 21 & 56,7 & 9 & 50 & 12 & 63,2 \\
\hline II & 8 & 21,6 & 5 & 27,8 & 3 & 15,8 \\
\hline III & 1 & 2,7 & 0 & 0 & 1 & 5,3 \\
\hline IV (guzkowa) & 6 & 16,2 & 4 & 22,2 & 2 & 10,5 \\
\hline
\end{tabular}


zarówno u dziewcząt, jak i chłopców była II klasa kłowa (Tabela 3). Najczęściej u 12-latków stwierdzano powiększony nagryz poziomy (81\%), typowy dla wad dotylnych. Prawidłowy nagryz poziomy odnotowano u $18,9 \%$. Prawidłowy nagryz pionowy występował u $27 \%$ dzieci, powiększony nagryz pionowy stwierdzono u 67,6\% (Tabela 4). U badanych 12-latków zaobserwowano zaburzenia położenia zębów. U 90\% badanych stwierdzono zrotowane zęby. Kolejnym zaburzeniem była protruzja - 24,3\%, następnie retruzja - 13,5\% i westibulo- pozycja - 13,5\%). Wśród chłopców dominowała rotacja i protruzja, zaś u dziewcząt rotacja i westibulopozycja, ektopia i protruzja. Zastosowana analiza statystyczna nie wykryła korelacji między występującymi wadami zgryzu i istniejącymi nieprawidłowościami zębowymi w grupie 12-latków (Tabela 5).

W grupie badanych 13-latków największy odsetek dzieci miał wadę dotylną - 48,7\%. Liczebnie prawie w równym stopniu dotyczyła ona dziewcząt (9 osób) i chłopców (10 osób). Wadę piono-

Tabela 3. Obustronna ocena klasy kłowej u 12-latków

Table 3. Bilateral rating classes for 12-year-olds

\begin{tabular}{|l|c|c|c|c|c|c|}
\hline \multirow{2}{*}{} & \multicolumn{2}{|c|}{$\begin{array}{c}\text { Razem } \\
\mathrm{N}=37\end{array}$} & \multicolumn{2}{c|}{$\begin{array}{c}\text { Dziewczęta } \\
\mathrm{N}=18\end{array}$} & \multicolumn{2}{c|}{$\begin{array}{c}\text { Chłopcy } \\
\mathrm{N}=19\end{array}$} \\
\cline { 2 - 7 } & $\mathrm{N}$ & $\%$ & $\mathrm{~N}$ & $\%$ & $\mathrm{~N}$ & $\%$ \\
\hline klasa kłowa strona prawa & \multicolumn{7}{|c|}{$\%$} \\
\hline I & 8 & 21,6 & 3 & 16,7 & 5 & 26,3 \\
\hline II & 23 & 62,2 & 13 & 72,2 & 10 & 52,6 \\
\hline III & 1 & 2,7 & 0 & 0 & 1 & 5,3 \\
\hline klasa kłowa strona lewa & \multicolumn{7}{|c|}{0} \\
\hline I & 10 & 27 & 4 & 22,2 & 6 & 31,6 \\
\hline II & 21 & 56,8 & 12 & 66,7 & 9 & 47,4 \\
\hline III & 1 & 2,7 & 0 & 0 & 1 & 5,3 \\
\hline
\end{tabular}

Tabela 4. Ocena nagryzu poziomego i pionowego u 12-latków

Table 4. Rating overjet and overbite for 12-year-olds

\begin{tabular}{|l|c|c|c|c|c|c|}
\hline \multirow{2}{*}{} & \multicolumn{2}{|c|}{$\begin{array}{c}\text { Razem } \\
\mathrm{N}=37\end{array}$} & \multicolumn{2}{c|}{$\begin{array}{c}\text { Dziewczęta } \\
\mathrm{N}=18\end{array}$} & \multicolumn{2}{c|}{$\begin{array}{c}\text { Chłopcy } \\
\mathrm{N}=19\end{array}$} \\
\cline { 2 - 7 } & $\mathrm{N}$ & $\%$ & $\mathrm{~N}$ & $\%$ & $\mathrm{~N}$ & $\%$ \\
\hline Nagryz poziomy & \multicolumn{7}{|c|}{} \\
\hline norma & 7 & 18,9 & 3 & 16,7 & 4 & 21,1 \\
\hline dodatni & 30 & 81,1 & 15 & 83,3 & 15 & 78,9 \\
\hline Nagryz pionowy & \multicolumn{7}{|c|}{} \\
\hline norma & 10 & 27 & 4 & 22,2 & 6 & 31,6 \\
\hline dodatni & 25 & 67,6 & 12 & 66,7 & 13 & 68,4 \\
\hline ujemny & 2 & 5,4 & 2 & 11,1 & 0 & 0 \\
\hline
\end{tabular}

Tabela 5. Częstość występowania zaburzeń położenia zębów w grupie 12-latków Table 5. The prevalence of teeth position in the group of 12 year olds

\begin{tabular}{|l|c|c|c|c|c|c|c|}
\hline \multirow{2}{*}{ Zaburzenia położenia } & \multicolumn{2}{|c|}{$\begin{array}{c}\text { Razem } \\
\mathrm{N}=37\end{array}$} & \multicolumn{2}{c|}{$\begin{array}{c}\text { Dziewczęta } \\
\mathrm{N}=18\end{array}$} & \multicolumn{2}{c|}{$\begin{array}{c}\text { Chłopcy } \\
\mathrm{N}=19\end{array}$} & \multirow{2}{*}{$\begin{array}{c}\text { Poziom } \\
\text { istotności }\end{array}$} \\
\cline { 2 - 7 } & $\mathrm{N}$ & $\%$ & $\mathrm{~N}$ & $\%$ & $\mathrm{~N}$ & $\%$ & \\
\hline ogółem & 37 & 100 & 18 & 100 & 19 & 100 & $\mathrm{NS}$ \\
\hline ektopia & 4 & 10,8 & 4 & 22,2 & 0 & 0 & $\mathrm{NS}$ \\
\hline transpozycja & 3 & 8,1 & 1 & 5,6 & 2 & 10,5 & $\mathrm{NS}$ \\
\hline protruzja & 9 & 24,3 & 4 & 22,2 & 5 & 26,3 & $\mathrm{NS}$ \\
\hline retruzja & 5 & 13,5 & 3 & 16,7 & 2 & 10,5 & $\mathrm{NS}$ \\
\hline distoinklinacja & 1 & 2,7 & 0 & 0 & 1 & 5,2 & $\mathrm{NS}$ \\
\hline vestibulopozycja & 5 & 13,5 & 5 & 27,8 & 0 & 0 & $\mathrm{NS}$ \\
\hline rotacja & 33 & 89,1 & 16 & 88,9 & 17 & 89,5 & $\mathrm{NS}$ \\
\hline reinkluzja & 1 & 2,7 & 0 & 0 & 1 & 5,3 & $\mathrm{NS}$ \\
\hline ząb zatrzymany & 1 & 2,7 & 0 & 0 & 1 & 5,3 & $\mathrm{NS}$ \\
\hline ząb przetrwały & 2 & 5,4 & 0 & 0 & 2 & 10,5 & $\mathrm{NS}$ \\
\hline
\end{tabular}


wą, charakterystyczną dla zgryzów otwartych lub głębokich, stwierdzono u $17,9 \%$, wadę doprzednią u $15,4 \%$, a wadę poprzeczną u 12,8\%. Spośród 39 badanych 13-latków 12 osób $(30,8 \%)$ miało zgryz prawidłowy (Tabela 6). Analiza statystyczna wykazała u 13-latków istnienie zależności pomiędzy wadą poprzeczną a spłaszczoną krzywą Spee $(p=0,0082)$, a na granicy istotności statystycznej pomiędzy istniejąca wadą doprzednią a pogłębiona krzywą Spee w łuku dolnym $(p=0,048)$. Potwierdzono istotną statystyczne korelację między istniejącą wadą dotylną a: II klasą Angle'a po stronie prawej $(p=0,00093)$ i po stronie lewej ( $p$ $=0,0071)$, II klasą kłową po stronie prawej $(p=$ $0,00000035)$ oraz lewej $(p=0,00083)$. Zaobser- wowano korelację istotną statystycznie pomiędzy występowaniem wady pionowej a powiększonym nagryzem pionowym ( $p=0,00074)$. Klasa I Angle’a u 13-latków występowała częściej po stronie prawej $(69,3 \%)$ niż po lewej $(62,5 \%)$. Inne klasy Angle'a występowały rzadziej (Tabela 7). I i II klasa kłowa były najczęściej obserwowanymi u 13-latków. Wśród dziewcząt dominowała klasa II po obu stronach $(56,3 \%$ - strona prawa i $62,5 \%$ strona lewa), natomiast u chłopców klasa I (56,5\% - strona prawa i 60,9\% - strona lewa) (Tabela 8). Nagryz poziomy w normie zgryzowej występował u 51,3\% badanych 13-latków, 48,7\% dzieci miało powiększony nagryz poziomy. Wśród dziewcząt $50 \%$ miało powiększony nagryz i 50\% prawidłowy

Tabela 6. Częstość występowania nieprawidłowości zębowo-zgryzowych u 13-latków

Table 6. The prevalence of dental-occlusal abnormalities in 13-year-olds

\begin{tabular}{|l|c|c|c|c|c|c|}
\hline \multirow{2}{*}{ Rodzaj nieprawidłowości } & \multicolumn{2}{|c|}{$\begin{array}{c}\text { Ogółem } \\
\mathrm{N}=39\end{array}$} & \multicolumn{2}{c|}{$\begin{array}{c}\text { Dziewczęta } \\
\mathrm{N}=16\end{array}$} & \multicolumn{2}{c|}{$\begin{array}{c}\text { Chłopcy } \\
\mathrm{N}=23\end{array}$} \\
\cline { 2 - 8 } & $\mathrm{N}$ & $\%$ & $\mathrm{~N}$ & $\%$ & $\mathrm{~N}$ & $\%$ \\
\hline wada poprzeczna & 5 & 12,8 & 3 & 18,8 & 2 & 8,7 \\
\hline wada pionowa & 7 & 17,9 & 3 & 18,8 & 4 & 17,4 \\
\hline wada dotylna & 19 & 48,7 & 9 & 56,3 & 10 & 43,5 \\
\hline wada doprzednia & 6 & 15,4 & 3 & 18,8 & 3 & 13,1 \\
\hline
\end{tabular}

Tabela 7. Obustronna ocena klasy Angle'a u 13-latków

Table 7. Bilateral rating class Angle for 13-year-olds

\begin{tabular}{|l|c|c|c|c|c|c|}
\hline \multirow{2}{*}{} & \multicolumn{2}{|c|}{$\begin{array}{c}\text { Razem } \\
\mathrm{N}=39\end{array}$} & \multicolumn{2}{c|}{$\begin{array}{c}\text { Dziewczęta } \\
\mathrm{N}=16\end{array}$} & \multicolumn{2}{c|}{$\begin{array}{c}\text { Chłopcy } \\
\mathrm{N}=23\end{array}$} \\
\cline { 2 - 7 } & $\mathrm{N}$ & $\%$ & $\mathrm{~N}$ & $\%$ & $\mathrm{~N}$ & $\%$ \\
\hline klasa Angle'a strona prawa & \multicolumn{7}{|c|}{} \\
\hline I & 27 & 69,3 & 10 & 62,5 & 17 & 73,9 \\
\hline II & 3 & 7,7 & 2 & 12,5 & 1 & 4,3 \\
\hline III & 4 & 10,3 & 2 & 12,5 & 2 & 8,7 \\
\hline IV (guzkowa) & 5 & 12,8 & 2 & 12,5 & 3 & 13,1 \\
\hline klasa Angle'a strona lewa & \multicolumn{7}{|c|}{} \\
\hline I & 24 & 61,5 & 10 & 62,5 & 14 & 60,9 \\
\hline II & 4 & 10,3 & 2 & 12,5 & 2 & 8,7 \\
\hline III & 8 & 20,5 & 3 & 18,8 & 5 & 21,7 \\
\hline IV (guzkowa) & 2 & 5,1 & 1 & 6,2 & 1 & 4,3 \\
\hline
\end{tabular}

Tabela 8. Obustronna ocena klasy kłowej u 13-latków

Table 8. Bilateral rating class Angle for 13-year-olds

\begin{tabular}{|l|c|c|c|c|c|c|}
\hline \multirow{2}{*}{} & \multicolumn{2}{|c|}{$\begin{array}{c}\text { Razem } \\
\mathrm{N}=39\end{array}$} & \multicolumn{2}{c|}{$\begin{array}{c}\text { Dziewczęta } \\
\mathrm{N}=16\end{array}$} & \multicolumn{2}{c|}{$\begin{array}{c}\text { Chłopcy } \\
\mathrm{N}=23\end{array}$} \\
\cline { 2 - 7 } & $\mathrm{N}$ & $\%$ & $\mathrm{~N}$ & $\%$ & $\mathrm{~N}$ & $\%$ \\
\hline klasa kłowa strona prawa & \multicolumn{7}{|c|}{$\%$} \\
\hline I & 18 & 46,2 & 5 & 31,3 & 13 & 56,5 \\
\hline II & 18 & 46,2 & 9 & 56,3 & 9 & 39,1 \\
\hline III & 2 & 5,1 & 1 & 6,2 & 1 & 4,3 \\
\hline klasa kłowa strona lewa & & & & & & \\
\hline I & 19 & 48,7 & 5 & 31,3 & 14 & 60,9 \\
\hline II & 17 & 43,6 & 10 & 62,5 & 7 & 30,4 \\
\hline III & 2 & 5,1 & 0 & 0 & 2 & 8,7 \\
\hline
\end{tabular}


Tabela 9. Ocena nagryzu poziomego i pionowego u 13-latków

Table 9. Rating overjet and overbite at for 13-year-olds

\begin{tabular}{|l|c|c|c|c|c|c|}
\hline \multirow{2}{*}{} & \multicolumn{2}{|c|}{$\begin{array}{c}\text { Razem } \\
\mathrm{N}=39\end{array}$} & \multicolumn{2}{c|}{$\begin{array}{c}\text { Dziewczęta } \\
\mathrm{N}=16\end{array}$} & \multicolumn{2}{c|}{$\begin{array}{c}\text { Chłopcy } \\
\mathrm{N}=23\end{array}$} \\
\cline { 2 - 7 } & $\mathrm{N}$ & $\%$ & $\mathrm{~N}$ & $\%$ & $\mathrm{~N}$ & $\%$ \\
\hline Nagryz poziomy & \multicolumn{7}{|c|}{} & \multicolumn{2}{c|}{} & \\
\hline Norma & 20 & 51,3 & 8 & 50 & 12 & 52,2 \\
\hline Dodatni & 19 & 48,7 & 8 & 50 & 11 & 47,8 \\
\hline Nagryz pionowy & & & & & & \\
\hline Norma & 23 & 59 & 10 & 62,5 & 13 & 56,5 \\
\hline Dodatni & 16 & 41 & 6 & 37,5 & 10 & 43,5 \\
\hline
\end{tabular}

Tabela 10. Częstość występowania zaburzeń położenia zębów w grupie 13-latków Table 10. The prevalence of teeth position in the group of 13 year olds

\begin{tabular}{|l|c|c|c|c|c|c|c|}
\hline \multirow{2}{*}{ Zaburzenia położenia } & \multicolumn{2}{|c|}{$\begin{array}{c}\text { Razem } \\
\mathrm{N}=39\end{array}$} & \multicolumn{2}{c|}{$\begin{array}{c}\text { Dziewczęta } \\
\mathrm{N}=16\end{array}$} & \multicolumn{2}{c|}{$\begin{array}{c}\text { Chłopcy } \\
\mathrm{N}=23\end{array}$} & \multirow{2}{*}{$\begin{array}{c}\text { Poziom } \\
\text { istotności }\end{array}$} \\
\cline { 2 - 7 } & $\mathrm{N}$ & $\%$ & $\mathrm{~N}$ & $\%$ & $\mathrm{~N}$ & $\%$ & \\
\hline Ogółem & 36 & 92,3 & 16 & 100 & 20 & 87 & $\mathrm{NS}$ \\
\hline Ektopia & 4 & 10,3 & 3 & 18,7 & 1 & 4,3 & $\mathrm{NS}$ \\
\hline transpozycja & 3 & 7,7 & 3 & 18,7 & 0 & 0 & $\mathrm{NS}$ \\
\hline Protruzja & 5 & 12,8 & 2 & 12,5 & 3 & 13 & $\mathrm{NS}$ \\
\hline Retruzja & 6 & 15,4 & 3 & 18,7 & 3 & 13 & $\mathrm{NS}$ \\
\hline distoinklinacja & 2 & 5,1 & 2 & 12,5 & 0 & 0 & $\mathrm{NS}$ \\
\hline palatopozycja & 4 & 10,3 & 3 & 12,7 & 1 & 4,3 & $\mathrm{NS}$ \\
\hline vestibulopozycja & 4 & 10,3 & 3 & 12,7 & 1 & 4,3 & $\mathrm{NS}$ \\
\hline Rotacja & 34 & 87,2 & 14 & 87,5 & 20 & 87 & $\mathrm{NS}$ \\
\hline ząb przetrwały & 1 & 2,6 & 0 & 0 & 1 & 4,3 & $\mathrm{NS}$ \\
\hline
\end{tabular}

nagryz poziomy. U 13-latków nie zaobserwowano odwrotnego nagryzu pionowego, prawie $60 \%$ dzieci miało nagryz pionowy prawidłowy, a powiększony $41 \%$ (Tabela 9). U 92,3\% badanych 13-latków stwierdzono zaburzenie położenia zębów. Zaburzenia położenia dotyczyły wszystkich dziewcząt i $87 \%$ chłopców. Najczęstszym zaburzeniem była rotacja i stanowiła $87,2 \%$, następnie retruzja 15,4\%, protruzja - 12,8\%. Przeprowadzona analiza statystyczna nie wykazała zależności pomiędzy występującymi wadami zgryzu a zaburzeniami położenia zębów (Tabela 10).

\section{Dyskusja}

Występowanie nieprawidłowości zgryzowych wśród dzieci w wieku szkolnym oraz czynników predysponujących do powstawania wad zgryzu jest od wielu lat przedmiotem dyskusji licznych autorów. W badanej grupie dzieci z powiatu kolskiego częstość występowania wad zgryzu była wysoka i wynosiła wśród 12-latków - 81,1\% i 13-latków $-69,2 \%$. Większy odsetek dzieci z nieprawidłowościami zgryzowymi był w grupie 12-latków. Ważne wydaje się, że badania dotyczące częstości występowania wad zgryzu u dzieci w wieku szkolnym nie były dotąd wykonywane we wschodniej Wielkopolsce. Należy także zaznaczyć, że ze wstępnie deklarujących się rodziców zgłosiło się z dziećmi do badania około $50 \%$. Świadczyć to może o tym, że rodzice/opiekunowie dzieci w wieku szkolnym nie doceniają korzyści płynących z uzyskanej po badaniu informacji. We wcześniejszych badaniach oceny występowania wad zgryzu dokonywano w niektórych regionach Polski: Myśliwiec i wsp. w województwie zachodniopomorskim w grupie 12-latków - 56,4\% i 13-latków - 75\% [10], Zadurska i wsp. w województwie mazowieckim w grupie 12-latków - 66,1\%, u 13-latków - 72\% [11]. Shahnazari [12] w swoich badaniach zaobserwowała u 12-latków województwa świętokrzyskiego wady zgryzu na poziomie $41,2 \%$, Rojek i Lisiecka u szczecińskich 12-latków stwierdziły 56,6\% wad zgryzu [2]. W naszych badaniach u 12-latków uzyskano wyższy odsetek, co wskazuje, że częstość wad zgryzu ma stałą tendencję wzrostową. Podobne wyniki badań dla grupy 13-latków uzyskano w Białymstoku - 64,5\% badanych [3]. Zdecydowanie większy odsetek wad zgryzu u dzieci w wieku 9-12 lat zaobserwowali Osmólska-Bogucka i wsp. [4] - 82\% badanych.

Badania autorów zagranicznych potwierdzają, że częste występowanie wad zgryzu dotyczy wszystkich populacji. $U$ nastolatek brazylijskich w wieku 13-15 lat stwierdzono większy odsetek $(91,4 \%)$ wad zębowo-zgryzowych [13] niż odnotowany w naszych badaniach. Podobnie jak u nasto- 
latków z powiatu kolskiego nie wykazano również zależności statystycznych pomiędzy wadą zębowo-zgryzową a płcią oraz wiekiem badanych. $\mathrm{U}$ nastolatek z kontynentu europejskiego także stwierdzono dużą częstość występowania wad zgryzu, stanowiącą od $40,4 \%$ do $84,6 \%$, co oznacza, że uzyskane przeze nas wyniki są porównywalne $z$ wynikami uzyskanymi w populacji europejskiej $(14,15)$. Wady dotylne stanowiły drugą co do częstości występowania nieprawidłowość dominowały wady zębowo-zgryzowe przy klasie I. Bliski Wschód, podobnie jak kontynent europejski, charakteryzuje duża rozbieżność w częstości stwierdzanych wad zgryzu, od $36,6 \%$ w Jemenie, $89,9 \%$ w Turcji, do $100 \%$ w Bejrucie $[9,16,17]$. W Afryce odsetek wad zgryzu jest również bardzo duży i wyraźnie zaznacza się w relacji do pozostałych kontynentów świata. W Casablance (Maroko) wyniósł on 95,4\% [18], w Libii 95,6\% [19], a w River State (Nigeria) stanowił $88,2 \%$ wszystkich zbadanych [6]. Zdecydowana większość to wady klasy I i II. Podobnie zaobserwowano w trzech miejscach w Indiach (Nalgonda, Pune, Maharashtra) i Wietnamie (Da Nang), gdzie odsetek wad zgryzu był duży i najczęściej stwierdzano wady klasy I i II [7, 20-22].

W zbadanych przez nas grupach 12- i 13-latków dominowały nieprawidłowości z grupy wad dotylnych, stanowiąc $50,9 \%$ ogółu $(70,3 \%$ - 12 lat, $48 \%$ - 13 lat), kolejno wady pionowe ( $18 \%$ ogółu), wady poprzeczne (12,4\% ogółu) i wady doprzednie $(8,1 \%$ ogółu). W badaniach polskich autorów również dominują wady dotylne (tyłozgyzy), a ich częstość występowania dochodzi do $62,2 \%$ [3, 4, $11,23,24]$. W innych krajach odsetek wad dotylnych jest zdecydowanie mniejszy i stanowi od 3\% do $44,7 \%$ [6, 7, 9, 18-21, 22, 25].

Nastolatki z powiatu kolskiego odznaczają się niemal $100 \%$ występowaniem nieprawidłowości zębowych dotyczących budowy: 12-latki 100\% i 13-latki 92-3\%. Najczęściej występującą nieprawidłowością była rotacja, stanowiąca od $79 \%$ u 10-latków do 90,5\% u 11-latków, drugą często wykrywaną była protruzja (12,8\% - 28\%). Grzybowska-Substelna i Pisulska-Otremba [26] odnotowały podobnie wysoki odsetek $(61,9 \%)$ wśród 12-latków z dawnego województwa opolskiego a prawie taka taka sama częstość nieprawidłowości zębowych (78\%) została wykryta przez Truszel i Roztoczyńską [27].

Wady zębowo-zgryzowe występujące u dzieci w wieku 12 i 13 lat nie były wcześniej badane we wschodniej Wielkopolsce. Pomimo braku inwazyjności metody oraz deklaracji rodziców, wykazujących chęć udziału w badaniu, na badanie zgłosiło się z dziećmi około 50\%. Powyższe niewątpliwie świadczy o braku świadomości z korzyści płynących z przeprowadzonych badań, jak również o konieczności propagowania działań edukacyjnych w tym zakresie.

\section{Wnioski}

Częstość występowania wad zgryzu u dzieci w wieku szkolnym w grupie 12- i 13-latków we wschodniej Wielkopolsce była wysoka, z przewagą wad zgryzu u dzieci 12-letnich.

\section{Oświadczenia}

Oświadczenie dotyczące konfliktu interesów

Autorki deklarują brak konfliktu interesów w autorstwie oraz publikacji pracy.

\section{Źródła finansowania}

Autorki deklarują brak źródeł finansowania.

\section{Piśmiennictwo}

[1] Onoszko M, Wojtaszek-Słomińska A, Rosnowska-Mazurkiewicz A. Występowanie wad zgryzu u 8- i 9-letnich dzieci z terenu Gdyni. Czas Stomat. 2007;60(3):195-201.

[2] Rojek R, Lisiecka K. Analiza stanu zgryzu 12-latków w dawnym województwie szczecińskim w latach 19872003. Mag Stomatol. 2009;1:20-24.

[3] Grodzka I, Szarmach I, Bugała-Musiatowich B. Zależności między nieprawidłowościami zgryzowymi a parafunkcjami w populacji młodzieży gimnazjalnej w Białymstoku. Dent Med Probl. 2009;46(3):311-318.

[4] Osmólska-Bogucka A. Buczek O, Bilińska M. Zadurska M. Parafunkcje niezwarciowe u dzieci i rodziców oraz ich wpływ na występowanie wad zgryzu u dzieci na podstawie badania ankietowego i klinicznego. Nowa Stomatol. 2014;2:63-69.

[5] Sieja A, Kawala B. Contemporary Ortodontic Diagnostics - Macroesthetic, Microesthetic, Miniesthetic. Dent Med Probl. 2014;51(51):19-25.

[6] Akinis EA, Onyeaso CO. Prevalence of malocclusion and occlusal traits among adolescents and young adults in Riverso State, Nigeria. Odontostomatol Trop. 2014 Mar; 37(145):5-12.

[7] Kumar M, Banerjee P, Gondhalekar R, Gondhalekar R, Lall R, Parwani R. Dental occlusion among school going children of Maharashtra. J Int Oral Health. 2014 Jul-Aug; 6(4):53-55.

[8] Feldens CA, Nakamura EK, Tessarollo FR, Closs LQ. Desire for orthodontic treatment and associated factors among adolescents in Southern Brazil. Angel Orthod. 2015 Mar;85(2):224-232.

[9] Hanna A, Chaaya M, Moukarzel C, El Asmar K, Jaffa M, Ghafari JG. Malocclusin in Elementary School Children in Beirut: Severity and Related Social/Behavioral Factors. Int J Dent. 2015;2015:351231.

[10] Myśliwiec et al. Lecznicze potrzeby stomatologiczne u dzieci i młodzieży z województwa zachodniopomorskiego. Zdr Publ. 2004;114(2):189-192,

[11] Zadurska M. i wsp. Wady zgryzu i zaburzenia funkcji układu mięśniowo-stawowego u dzieci w wieku 10-13 lat. Ortop Szczęk Ortod. 2005;2:14-18.

[12] Shahnazari A. Estetyka uzębienia pacjentów w wieku 12 lat $z$ województwa świętokrzyskiego. Mag Stomat. 2005;XV(12):74-77.

[13] Marques CR, Couto GB, Orestes Cardoso S. Assessment of orthodontic treatment needs in Brazilian schoolchildren according to Dental Aesthetic Index (DAI). Community Dent Health. 2007;24(3):145-148.

[14] Sidlauskas A, Lopatiene K. The prevalence of malocclusion among 7-15-year-old Lithuanian schoolchildren. Medicina Kaunas. 2009;45(2):147-52. 
[15] Laganà G, Masucci C, Fabi F, Bollero P, Cozza P. Prevalence of malocclusion, oral habits and orthodontic treatment need in a 7 - to 15 -year-old schoolchildren population in Tiran. Prog Orthod. 2013;14:12.

[16] Gelgr IE, Karaman AI, Ercan E. Prevalence of malocclusion among adolescents in central Anatolia. Eur J Dent. 2007;1(3):125-131.

[17] Al-Zubari Nabil Muhsen: Orthodontic treatment need of Yemeni children assessed with dental aesthetic index. J Orthod Sci. 2014;3(2):41-45.

[18] Bourzgui F, Sebbar M, Hamza M, Lazrak L, Abidine Z, El Quars F. Prevalence of malocclusion and orthodontic treatment need in 8-12-year-old schoolchildren in Casablanca, Marocco. Prog Orthod. 2012;13(2):164-172.

[19] Bugaighis I, Karanth D. The prevalence of malocclusion in urban Libyan schoolchildren. J Orthod Sci. 2013;2(1):1-6.

[20] Reddy ER., Manjula M, Sreelakshmi N, Thabitha Rani S, Aduri R, Dharamraj Patil B. Prevalence of malocclusion among 6 to 10 year old Nalgonda school children. J Int Oral Health. 2013 Dec;5(6):49-54.

[21] Kumar P, Londhe SM, Kotwal A, Mitra R. Prevalence of malocclusion nad orthodontic teratment need in schoolchildren - an epidemiological study. Med J Armed Forces Indi. 2013;69(4):369-374

[22] Nguyen SM, Nguyen MK, Saag M, Jagomagi T. The need of orthodontic treatment among Vietnamese school children and young adults. Int J Dent. 2014;132301.

[23] Ziemiańska-Maczek J. Częstość występowania wad zgryzu u dzieci jedenastoletnich z terenów wiejskich powiatu nowotarskiego województwa małopolskiego. Implantoprotetyk. 2007;8(3):40-42.
[24] Kozanecka, Kawala B. Częstość występowania wad zgryzu a potrzeba leczenia ortodontycznego w populacji młodych dorosłych Polaków - przegląd piśmiennictwa. J Stoma. 2012;65:424-34.

[25] Laganà G, Masucci C, Fabi F, Bollero P, Cozza P. Prevalence of malocclusion, oral habits and orthodontic treatment need in a 7- to 15-year-old schoolchildren population in Tiran. Prog Orthod. 2013;14:142.

[26] Grzybowska-Substelna J, Pisulska-Otremba A. Częstość występowania wad zgryzu u dzieci i młodzieży województwa opolskiego. Czas Stomat. 2001;LIV(1):51-56.

[27] Truszel M, Roztoczyńska A. Ocena stanu zdrowia narządu żucia dzieci 12-letnich w Bielsku-Białej. Mag Stomatol. 2002;XII(10):48-52.

Zaakceptowano do edycji: 2017-03-12 Zaakceptowano do publikacji: 2017-04-22

\author{
Adres do korespondencji: \\ Kornela Cieślik \\ Zakład Organizacji i Zarządzania w Opiece Zdrowotnej \\ Uniwersytet Medyczny im. Karola Marcinkowskiego \\ w Poznaniu \\ ul. Smoluchowskiego 11, 60-179 Poznań \\ tel.: +48 605975693 \\ e-mail: kcieslik@ump.edu.pl
}

